\title{
SOURCES AND INSTRUMENTS OF FINANCING \\ FOR THE EUROPEAN ENERGY SECTOR: \\ A COMPARATIVE ANALYSIS BETWEEN PRIVATE, PUBLIC AND MIXED INSTRUMENTS
}

Corina MURAFA ${ }^{1}$

\begin{abstract}
While Public Private Partnerships exhibit a bunch of political, economic and implementation risks, they seem the best fit to address the existing financing gaps in the European energy sector, in contrast to purely private or purely public financing instruments. Due on the one hand to the politicization of the energy sector and on the other hand to the limitations of financial actors to engage in the provision of patient capital, governments are having a more intrusive role in the financing of the European energy sector.

European institutions are also increasingly using their own budgets as leverage-based financial instruments. Through a comprehensive literature review and case studies on the Connecting Europe Facility and the Project Bond Initiative, I argue that a bunch of investments would not be possible without a mission-driven role of the state. usuallv in the form of guarantees and other mixed instruments.
\end{abstract}

Keywords: energy policy, energy sector, Energy Union, Public Private Partnerships, project finance, financing instruments

JEL classification: F00, F21, F30, F50, F55, G15, G18, G23, G28, G32, H54, H81, L95, L97

DOI: $10.24818 / \mathrm{RMCI} .2019 .3 .360$

\section{Introduction}

The current article will present and discuss three types of financing for the European energy sector: purely private financing, purely public financing and the mix of the two, namely public private partnerships (PPPs). The chapter will make a literature review of each of these instruments and, based on this analysis, identify limitations and advantages of all these financing instruments, not from a theoretical perspective only, but based on the actual evolution of the European energy sector. The policy significance of the research comes from the obvious reality that the current investment patterns and instruments in the energy sector in the European Union (EU) will not deliver the necessary amount of investment in the sector, to

${ }^{1}$ Corina Murafa, The Bucharest Academy of Economic Studies, Romania,

E-mail: corina.murafa@gmail.com 
ensure its sustainability and competitiveness. The European Investment Bank assesses there is a yearly gap in investments necessary to ensure the EU's compliance with the 2030 targets of EUR 100 billion, with $70 \%$ of it being in energy efficiency savings in buildings and industry, $18 \%$ in upgrading energy networks (gas and electricity), and $12 \%$ in power generation, including renewables (EIB, 2016).

\section{Purely private financing: classical lending, project finance, bonds: Limitations in the current economic landscape}

Traditionally, the European energy sector has been financed by large utilities. Utilities are "companies that collect the majority of their total revenues and cash flows through the generation, storage, transmission and/or distribution of electricity, heat and/or gas from facilities it owns and/or operates" (Scope, 2016). The traditional utility model, a vertically integrated one, posed relatively low risks, so therefore was very appealing to institutional investors. Until recently, large utilities still continued to play a significant role in financing the European energy sector, including when it came to new capacity; this was largely due to their credit worthiness and capacity to obtain large amounts of corporate debt with negligible impact on their balance sheet (Lam and Law, 2018). In the UK for instance, but figures are similar for other European countries as well, approximately $85 \%$ of the new capacity financed between 2006 and 2012 has been built by major utility companies (BNEF, 2012), a total of $14 \mathrm{GW}$.

However, given the aftermath of the global financial crisis, new prudential requirements in the banking sector and the imperative of the energy transition, "many European power utilities have frozen their investment plans in the face of an increasing debt burden and the challenge to their traditional business model from renewable energy. (Ernst \& Young, 2014)". Since the crisis, companies themselves have been struggling with very low margins. Authors point out that, "for the top 25 European utilities as a whole, the earnings margin is set to remain well below prerecession levels" (Blyth et al, 2015). This is due to the fact of excess capacity and penetration of renewables which led, in turn, to persistently declining wholesale power prices. As a result, utilities have cut down on further CAPEX investments, despite the need to invest in grid modernization (due to ageing assets and the need to accommodate intermittent renewables). There has been a marked deterioration of credit worthiness (Blyth et al, 2015; Scope, 2016) and simultaneously an increase in utilities indebtedness in some cases by a ratio of ten fold in the past ten years. Access to credit considerations and the tortuous interplay between the financial markets and the energy markets will, most likely, shrink the space for this type of private financing of the European energy sector. Authors point out that, given the transformation of the financial sector, it will become an ever less reliable partner of the energy sector. With tighter regulations in Europe (Basel III, etc.), commercial banks' appetite for lending to utilities is diminishing. Furthermore, banks seem to be increasingly more attracted to speculative, rather than long-term 
investment and thus uncapable of financing the real economy; unless the financial system gets a massive shake-up, it will be totally defeated when it comes to financing the energy sector (Jacobsson \& Jacobsson, 2012). Private finance is increasingly accused by scholars as short-termist and withdrawing from real economy, which, in turn, becomes increasingly financialized (Haldane, 2011; Kay, 2012; Mazzucato and Pena, 2015; Dore, 2008).

If classical private investment in the form of commercial bank lending or own investments from accumulated earnings is less and less likely in the future, given the increasing financing gap, a solution might be a more sophisticated type of private financing, namely project finance. Project finance has existed since the $13^{\text {th }}$ century, some authors claim (Finnerty, 2007), and until modern times it was only used for particularly large investment projects (mines, offshore oil, etc.), while it extended to mid-size projects in the 1990s and became established as a discipline in structured finance (Kayser, 2013).

As a matter of fact, when discussing private finance for the energy sector, most of it took the form of project finance in the past ten years, rather than classical lending. Within the broader field of project finance, while at the beginning it was more focused on transport, in recent years "three sectors account for the lion's share [two of them being in the energy field]: power generation, oil \& gas, and transport infrastructure" (Thomson Reuters, 2016). Even in 2012, Europe remained in 2012 the most attractive region for project finance in terms of number of deals closed in the field of infrastructure (EY, 2014). The most common definition for project finance is: "a non-recourse or limited recourse financing structure in which debt, equity and credit enhancement are combined for the construction and operation, or the refinancing, of a particular facility in a capital-intensive industry." (Fight, 2008). Project finance, by definition "more patient" than traditional equity, is playing such an important role in financing the European energy sector. While in general project finance in the energy sector has been used to finance very large and complex projects, recently a surge in low- to medium-sized RE-oriented investments appeared (Steffen, 2018). Empirical analysis conducted over a vast data set of RE projects from Germany from the past ten years (Steffen, 2018) revealed that, while utilities rarely resort to project finance and prefer corporate loans, financial investors, citizen-owned structures and project developers almost always resort to project finance.

Non-recourse or limited recourse is one of the key features of project financing. Oftentimes, the borrowing entity is a special purpose vehicle with no credit history and in many cases the size of the project dwarves the size of the participating companies' balance sheet. What will be encountered in practice more often however is limited recourse project financing. Non-recourse or limited recourse financing is one of the main advantages as it does not impose any obligation to guarantee the repayment of the project debt on the project sponsor. A second advantage is off balance sheet debt treatment, which isolates project risk, so that a potential failure of the project doesn't damage the owner's financial conditions. Another advantage is favourable tax treatment and leverage debt 
(which ensures the avoidance of share issues and thus equity dilution). Other advantages are: favourable financing terms, political risk diversification, risk sharing (the lender also shares in the risk). Furthermore, the collateral is limited only to the project assets, and lenders are more likely to participate in working out a solution in case the project encounters difficulties, rather than foreclose. Classical motivations for project finance are "the prevention of contamination risk, and agency conflicts" (Steffen, 2017).

The disadvantages of project financing, on the other hand are: complexity of risk allocation, increased lender risk, higher interest rates and fees, lender supervision in the project, increased insurance coverage, and the fact transaction costs may outweigh the benefits (Fight, 2008). With the onset of tighter prudential regulations in Europe (e.g.: Basel III, Solvency II), commercial banks are preparing for the implementation of higher capital requirements, so their appetite for project finance is reduced, because mature low-carbon innovation still displays an unfavourable risk/ return relationship (Polzin, 2017).

However, as a result of the collapse in all the traditional instruments for financing infrastructure, a significant decrease in general infrastructure financing in Europe has occurred. The value of project financed infrastructure declined by more than half between 2010 and 2012 - see Figure below (EY, 2014).

While project finance, and especially re-financing, gradually picked up after 2013 (Standard \& Poor's, 2013), especially for wind projects (Mazars, 2012), it still remained limited and arrangements became and more complicated, involving a mix of equity (on-balance) owned by consortia of utilities and debt, in the form of project finance supplied by banks (off-balance); at the same time thought, a hybridization with public sources (in the form of guarantees, at least) became more and more frequent (Blyth et al, 2015).

However, it seems that financing the sustainability of the European energy sector is less a question of the availability of private financing ( $\mathrm{Lu}$ et al, 2015), but of its directionality (Mazucatto, Pena, 2015), though there are also contrasting voices, economics-driven, that argue that "the availability and cost of capital is crucial for successful energy transitions" (Steffen, 2017). Statistics vary, but fact of the matter is that private institutional investors do not seem to be oriented strongly enough towards green energy technologies, which are crucial for tackling climate change and, due to primary fuel availability in Europe, even European energy security. This perspective is supported by Mazzucato and Semieniuk (2015), who use Bloomberg New Energy Finance data series (checking them against UNEP estimates), to conclude that "fossil fuel investments continue to dwarf investments into renewable energy"; at global level, in 2013, the renewable sector received only $16 \%$ of the total USD 260 billion that the energy sector mobilized in capital, despite the fact it actually has had, between 2004 and 2014, a compound annual growth rate of $18 \%$ along the entire innovation chain, from research and development to asset finance.

A closer look at private institutional investors with typical long-term horizons (e.g.: pensions, insurance and private wealth funds) is worth the while, 
given the fact there seems to be an overlap in the incentives between energy sector assets (long payback times) and institutional investors (long investment lifetime) Kaminker and Stewart, 2012, Badreddine et al, 2012, etc. Authors are talking even about "a near perfect match" and also about other elements of technical alignment, such as hedging pension funds' sensitivity to inflation (Lu et al, 2015). Despite this theoretical match, infrastructure assets are, in reality, rarely financed by institutional investors; for instance, only $1 \%$ of assets under management by pension funds, at global level, are infrastructure assets (Inderst, 2013). Presumably, an increase by a couple of percentages would lead to a possible filling of the investment gap that persists in the sector to date.

Green/ climate bonds are appealing to some authors from an ideological/ normative perspective: "if capitalist industrialism created the problem [climate change] in the first place, then in our view a way has to be found for capitalist processes to solve the problem" (Mathews et al, 2010) and truly indispensable in the context of climate change adaptation and mitigation, given the unlikely creation of a massive carbon tax scheme (Baker et al, 2018). At a time when institutional investors are looking for safe havens, renewable energy futures may be also a pragmatic solution. A point in case are the US \$ 2.2 billion of Green Bonds issued by the US Treasury in 2009, or the Climate Awareness Bonds, fully subscribed, issued by the EIB. While the vast majority of them are actually issued by public lenders (e.g.: World Bank, EIB, etc.) so should be treated as a public source of financing, there are also green bonds issue by private entities, albeit usually backed by some form of public support (e.g.: tax exemptions or tax credits). In 2017 alone, the green bond market had gone to a record high, accounting for US \$ 161 billion worth of investment worldwide (Moody's, 2017). In any case, they seem to be specifically apt as a method of refinancing project operational cash flows, as they are liquid and very easily tradable and bring a lower cost of capital (Caldecott, 2010). Even in the case of the primary market, the positive evolution of green bonds, despite lower financial returns, can be explained by the rise in ethically concerned investors, willing to accept lower financial gains in order to meet social objectives (Renneborg et al, 2008). With the current policy evolutions in the European energy sector it may seem that, in the mid- to long-term future, investments in carbon-intensive assets will have been such a poor decision, that they are actually nowadays considered stranded assets (Polzin, 2017).

\section{Public financing of the energy sector: the inevitable risk of hard politics}

When discussing purely public finance as a source of financing for the European energy sector, one should look, in general, at the government's role in financing the economy, with a specific focus on on infrastructure, innovation and also the different parts of the business chain in the energy sector.

A great portion of economic theory is dedicated to the deficiencies and limitations of public authorities as active economic actors (i.e.: investors). Mitchell 
(1993) stresses that public authorities are less efficient, less innovative, and less accountable than private or other forms of ownership and management, and are subject to the short-termism of election cycles. Not only is political interference a risk for sound decision-making on investment destinations, but the multitude of stakeholders and societal groups decision-makers must take into account leads to lengthy negotiation processes and high transactional costs (Pagano and Perry, 2008), while in general taxes as a source of infrastructure finance are criticized because of inherent political disputes, competing political priorities and demands, voter revolts, etc. (Ingram and Hong, 2012; Steuerle, 2014).

However, given the market failures and the negative externalities displayed by the current setup of the European energy market, there is a need for government intervention. The question is through which instruments and to what objectives. Panel econometric data shows that the lack of public investment has restricted private investment and thus GDP growth in the EUR area (Dreger and Raimers, 2016).

Investment by the public sector beyond the R\&D stage was justified not just through market failures, but also through so-called mission-oriented projects/ policies, which led to the creation of whole new sectors (e.g.: low carbon tech). The trend, authors claim, is still needed in the future, to push to market towards "workable solutions to increase grid flexibility, e.g., energy storage and smart grid solutions" (Lindquist, 2017), as a matter of budgetary priority for both national governments and the Commission/ EIB. Such an intervention consisting of "deep investments" across the entire innovation chain is usually driven by state-owned development banks, which represent "an institutional model to help reform the financial system from within and to achieve smart innovation-led growth" (Mazzucato and Penna, 2015).

Mazzucato and Semieniuk (2015), albeit when looking only at renewable energy investments, confirm that "a dramatic shift took place from an asset finance market supplied in 2004 up to $90 \%$ by private finance to a market with almost equal splits between private and public sources in 2014 [...] in other words, since 2009, public actors have supplied well over a third of global RE asset finance, and in some years almost half'. Still, given the reduced fiscal space available for most individual governments in the EU, it will be most likely public financing in the form of European grants that will advance key priorities in the sector.

In theory a great idea for supporting investments that are not bankable, like cross-border interconnection projects, the financing needs of the European energy sector are far greater than what the EU budget can cover through classical grant instruments. At the same time, some voices claim, it's worth also to spare the resource through an efficient use of existing cross-border infrastructure (achievable through regulation) rather than through investments in new assets (Carlini et al, 2019). This argument is further backed by the fact that, both literature and case studies point out, the apparent gridlock when it comes to interconnectors is due to "political and governance-related issues rather than economics and finances" (Puka and Szulecki, 2014). When we discuss the public financing of the European energy 
sector, it becomes apparent that the pooling of resources (so adjusting the level of governance to a higher tier) is highly contentious. Most of the multi-year public investment programmes occurred at national or even municipal level; Connecting Europe Facility is a notable example and still, had it not be a sovereign control over the financial allocation, the multi-national governance level would have led to even greater delays in project implementation.

The Connecting Europe Facility (CEF) is an excellent case study on public investments towards the sustainability and competitiveness of the European energy sector. Given the serious difficulties faced by the European energy sector in terms of designing bankable energy infrastructure projects and also in attracting the necessary financing for them, coupled with the imperative to complete the Single European Energy market, the energy sector was included in the so-called Connecting Europe Facility (CEF). CEF is a large package of public support for trans-European network projects, included in the 2014 - 2020 Multiannual Financial Framework. CEF should also be seen as one of the few concrete mechanisms of enforcing European solidarity - a new value in European energy policy - because "Making the necessary investments in grid upgrades and sustained financial support to RE deployment during economic recession and growing unemployment is difficult and creates serious tensions between richer and poorer countries in regard to common EU spending on grid infrastructure projects." (Lindquist, 2017).

Many energy projects (most of them crossborder or with a crossborder impact) proposed by Member States compete for the funding available in the CEF facility. They are the so-called Project of Common Interest (PCI projects) analysed and evaluated at EU level. At the moment, the Commission has agreed on 248 PCIs proposed by Member States, with the list being updated every 2 years. These projects benefit from accelerated licensing procedures, improved regulatory conditions and most importantly access to financial support totalling EUR 5.85 billion from the Connecting Europe Facility (CEF) between 2014 and 2020 (in 2014 EUR 647 million have been accessed). However, this is just 3\% of investment needs until 2020.

The projects accepted so far under the energy branch of the CEF instrument comprise involve electricity transmission lines, gas pipelines, electricity storage projects, underground gas storage projects, LNG terminals and smart grid projects. However, there has been heavy criticism both as to how the selection has been made and with respect to the results. Environmental stakeholders maintain that "there have been significant procedural weaknesses involving lack of transparency and limited stakeholder consultation during the preparation of the first EU list of energy infrastructure projects of common interest" (Birdlife, 2013). In addition, the end result seems to favour projects that actually go against the EU's environmental policy goals, like, for instance the on-shore LNG terminal in Northern Adriatic (formerly known as Zaule LNG terminal), Italy (PCI 6.19). , critics claim that the current list of shortlisted projects defeats the general broad objectives of EU energy policy, relying too much on gas projects to the detriment 
of electricity ones (Gaventa, 2014). The figure below summarizes the critique in a telling manner:

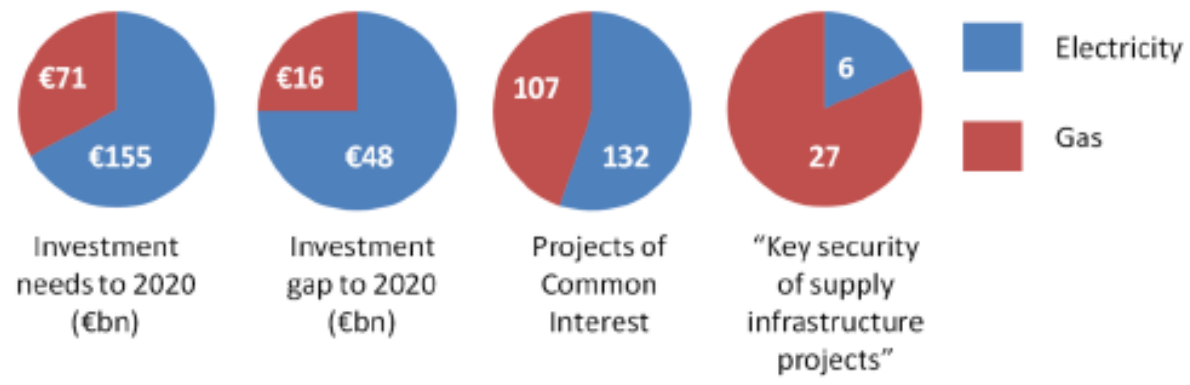

Figure 1: The CEF Project Prioritization is Wrongly Favouring Gas against Electricity Source: Gaventa, 2014

In reality, public investments in the energy sector at community level, such as CEF, are much more than just economics. They are hard politics and denote significant and intense geopolitical negotiations. This is also due to the fact that energy is, in reality, a highly politicized commodity and it "has been at the core of the European integration project from the very start" (Lindquist, 2017). The package on the Energy Union, authors claim, is a success by the Eastern block in the EU (led by Donald Tusk) to impose a "securitized" approach to energy policy, as opposed to the typical market/ liberalization-based approach of Western Member States. CEF is thus an "interventionist supplement" to the regulatory approach of creating a Single European Market (Austvik, 2016), which is a clear evidence of the transition of EU energy policy from a "markets and institutions" approach to a "regions and empires" approach (Correlje and van der Linde, 2006). While CEF is claiming to be financing a wide array of projects that foster EU energy policy, as demonstrated above, it is clearly favouring gas interconnections, which - given the geopolitical background of the EU - Russia disputes in the natural gas field - is clear evidence that CEF is not an investment instrument per se, but a geopolitical/ foreign policy one that goes into the "regions and empires" approach.

\section{Public - Private Partnerships: Not a silver bullet, but definitely the preferred alternative}

With the given limitations of both exclusively private and exclusively public finance, are public private partnerships (PPPs) a solution? In their classical form known to date, they also seem to have hit a crisis point. As research points out, "private investors now seek to reduce their risk" (Cuttaree, Mandri-Pierrot, 2010), meaning a significant flight to less risky countries has started to occur.

While, the lack of a consensual narrow definition of a PPP is what turns this concept into a catch-all notion, from studying existing literature on energy PPPs in Europe and elsewhere, the main conclusion I came to draw is that all current financing instruments that are being used for financing large energy projects in Europe, despite their different shapes and formats, can be classified as one of PPP. 
Because PPPs can take many forms and shapes and due to the lack of a unified classification and monitoring system of PPPs across the EU, it is difficult to trace an exact history of energy PPPs. The most comprehensive overview of PPPs in Europe made by the European PPP Expertise Center (EPEC), covering a period between 1990 and 2010, takes a rather conservative definition of what a PPP is, so many energy PPPs that have been implemented so far in the energy sector are not accounted for. In my opinion, given that new investments in energy transport and distribution- even those done solely on the balance sheet of the private utility owner - are pursued only with a guaranteed rate of return for a long period of time (via regulation), it is rather restrictive not to consider them a form of PPP as well. Anyhow, even with the abovementioned conservative definition in mind, the history of energy PPPs in Europe is impressive.

For sure, if one takes into consideration the rather narrow definition promoted by EPEC and EIB, few energy projects qualify as PPPs. However, in my opinion, even if one abides by the features of PPPs mentioned in the current EPEC Guide on PPPs (EPEC, 2013), many energy PPPs - including investments by large utilities (concessioners actually of transmission and distribution networks) could qualify as PPPs. The EPEC Guide mentions that PPPs share the following typical features: a long-term contract between a public authority and a private sector company; the transfer of a certain project risk to the private sector; a focus on project outputs rather than inputs (striking thus a significant difference from conventional PPPs); an application of private financing; payments from the private sector which reflect the services delivered (either through user charges, by the Authority or by a combination of both).

Taking the Energy Efficient Buildings PPP as a case study, one can draw certain conclusions as to the general features of a PPP in the energy sector. This PPP, although smaller in terms of the public contribution (EUR 600 million) than the European Green Vehicles Initiative (EUR 1.5 bn), is quite exemplary, as the first one of its kind proposed by European institutions. Firstly, the counterpart to the public sector (in this case the European Commission) is a special-purpose association representing the private sector - the Energy Efficiency Buildings Association (E2BA). This PPP has been launched as early as December 2008, under the European Economic Recovery Plan. It contained very clear quantitative objectives: to increase private investment in research and innovation up to $3 \%$ turnover; to create 10 new types of high-skilled jobs implemented through knowledge transfer and training; to develop the technology to reduce energy and $\mathrm{CO} 2$ by $50 \%$ and by $80 \%$ respectively compared to 2010 levels; to present at least 100 demonstration buildings and districts, retrofitted with ICT-based solutions and monitored to achieve up to $75 \%$ energy use. The private side - E2BA - committed to attract private funding.

Historical evidence shows that indeed PPPs have led to savings, in contrast to what would have been the case in case either solely the private or the public partner delivered the investments. These have been estimated to range between 10 and 30\%, with the most notable overview being done in the UK (Graeme and Greve, 2007). 
Another interesting case of a classical PPP in energy, partially financed by the EIB, has been the London Underground Electricity Supply and Distribution. This particular PPP has been part of a wider range of PPPs started in 2002 - 2003 by local authorities in London, namely the so-called London Underground Limited Public-Private Partnerships (LUL PPPs). They are unique in terms of complexity and scale and also renowned for their notorious failure as public policies, as all three concessionaire companies the London authorities had engaged in 30-year PPPs with for the expansion, maintenance and operation of the London Underground, fell into administration and the public sector ended up taking over all of the three PPPs. The reason local authorities had engaged in PPPs in the first instance was the poor performance of the public sector in the expansion and running of the lines to begin with. For several large line expansions in the mid-1990s, done entirely with public sector participation, there had been cost overruns of over 30\%. A comprehensive research paper showing the complexity of the LUL PPPs failure and drawing significant lessons from it, authored by Varun Hallikeri (2012) uses process tracing to identify the history and causes of this public policy failure. According to Hallikeri, for just two out of the three PPPs, ran by the same concessionaire, the investment commitments of the private party (Metronet) over the 30 year period of the project exceeded GBP 17 billion, in form of maintenance, renewal and expansion works of the Tube's infrastructure. The private concessionaires accessed, among others, financing from the European Investment Bank for this highly ambitious PPP. While the bulk of EIB money (over EUR 1.3 billion) went into the transportation only PPPs, there was also a much smaller PPP in the energy sector, a 30 -year contract to operate, maintain, finance and renew London underground's high-voltage distribution network. The EIB loan for this particular PPP stream was only EUR 71 million (and it was designed for CAPEX works in the initial phase of the project). In 2002, a new loan was requested from the EIB, but the project had already started to encounter difficulties. A special-purpose vehicle company, Seeboard Powerlink, was awarded this contract, and it thus became responsible for distributing high-voltage power to London Underground's 270 stations and also for supplying power to the $400 \mathrm{~km}$ of track. The overall value of the contract was far greater than the EIB loan, namely EUR 1.6 billion. The payment arrangement for the project has been performance-based availability payment, in the form of a monthly indexed infrastructure service charge. As it usually happens with PPPs and privatizations, given the emotional load of the topic, subsequent failures came to be blamed on the concessionaries, and the PPP itself went under the radar. Thus, in 2003 a massive black-out occurred in London, which left large parts of the capital without electricity and brought the transport network to a halt. Dozens of trains were left stuck in the tunnels, and tens of thousands of tube passengers were affected. Seeboard Powerlink was blamed for exacerbating the black-out and for failing to assure the necessary back-up (Clark, 2003). The transportation union in London took the opportunity to criticize heavily the PPP model that was the prevailing modus operandi for delivering public services in UK at the time. Although not a failure as spectacular as the PPPs for the transportation part themselves, the power 
PPP also ended up failing. Thus, in August 2012, the London Underground announced that next year it would express its option of terminating the 30-year private finance initiative power network contract with Seeboard Powerlink half-way through the contract, by exercising the half-way break clause. The Powerlink consortium received GBP 160 million in termination payments, but the London Underground company claimed that by the early termination of the contract it actually saved over GBP 220 million over the lifetime of the contract, through avoiding expensive financing costs. Increased operational flexibility, allowing for greater savings in further transport improvements, were invoked by the London Underground management as further advantages from an early termination of the contract, although their assessment at the time of this decision was that the contract "was performing well" (Railway Technology, 2012).

In the aftermath of the global financial crisis, given the impact on the PPP market described in the previous section and also the financing imperative of the European energy sector (as described in the introductory section of this paper), European authorities realized they needed to go beyond the traditional model of PPP to harness the full potential of public-private cooperation and to leverage enough private funding in Europe's aging energy assets (first and foremost, its interconnections, but also its generation assets), in addition to the funding that European institutions would have been able to commit from their own budgets.

The Project Bond Initiative (PBI) was rolled out on a pilot basis at the beginning, with the aim of reviving and expanding capital markets to finance large European infrastructure projects in the fields of transport, energy and information technology. It is a joint initiative between the European Commission (EC) and the European Investment Bank (EIB), established by Regulation No. 670/220 (as of 31 July 2012). The working mechanism behind the initiative is basically to enhance the credit worthiness of project bonds issued by private companies, through the intervention of the $\mathrm{EC}$ in the traditional lending process of $\mathrm{EIB}$, as to attract institutional investors from capital markets. It is a unique financing instruments because of its supranational scope, long tenor and open structure.

The time horizon for implementing the pilot phase has been very short covering only half of 2012 and the entire year 2013. Apparently, the budget allocation for the pilot phase has been quite high - EUR 230 million from the EC budget. However, a minuscule portion of this has been dedicated to energy projects, namely EUR 10 million, representing a re-allocation from the TEN-E (Trans-European Energy Networks) budget. As mentioned above, the EC contribution was supposed to cover a proportion of the risk the EIB is taking when financing eligible projects, essentially through a credit enhancement. The estimate of European institutions in the pilot phase has been that a combination between EC funding and EIB financing would achieve a multiplier effect of around 3, with the EIB enhancing up to $20 \%$ of the project debt, and thus achieving an even higher final multiplier effect. In a simple calculation, the total EUR 230 million budget was supposed to mobilize investments of up to EUR 4.6 billion (European Commission, 2013). 
Up to the end of the pilot project, nine energy and transport projects, in six EU countries, have turned out to be eligible for credit enhancement and approved by the EIB board. These include classical motorway projects, but also grid connections to offshore grid farms and gas storage facilities. It is interesting that, for the first time, energy projects score close to transportation project, usually much more prone to being undertaken in a PPP type of arrangement.

The Midterm evaluation report of the PBI pilot phase (Ernst \& Young, 2014) indicates that a facility such as the PBI is very welcomed by the market, as the pipeline of investment grade (i.e. above BBB-rated) infrastructure projects is currently very low in Europe. The EC - EIB initiative, by the risk guarantee it offers, might uplift the rating of lower-rated projects and thus make them investment grade. This should be especially useful in riskier Member States of the EU (e.g.: Southern and Eastern Europe) and also for newer technologies - such as renewable sources. It could thus be argued that this financing instrument fixes a market failure - the mismatch between the demand of institutional investors ${ }^{1}$ and the supply of investment ready infrastructure projects.

Three press clippings on the website of the European Commission present energy projects that have successfully secured financing in the PBI pilot phase.

Table 1: Case studies of the three energy projects financed under the PBI pilot phase

\begin{tabular}{|l|l|l|l|}
\hline \multicolumn{1}{|c|}{$\begin{array}{c}\text { Gwynt y Mor } \\
\text { offshore } \\
\text { transmission link }\end{array}$} & $\begin{array}{c}\text { Greater Gabbard } \\
\text { offshore } \\
\text { transmission link }\end{array}$ & \multicolumn{1}{|c|}{$\begin{array}{c}\text { Castor energy storage } \\
\text { project }\end{array}$} \\
\hline Country & UK & UK & Spain \\
\hline $\begin{array}{l}\text { Total budget } \\
\text { bonds issued } \\
\text { by the project } \\
\text { promoters) }\end{array}$ & GBP 352 million & GBP 305 million & EUR 1.4 billion \\
\hline $\begin{array}{l}\text { Total value of } \\
\text { backing from } \\
\text { EIB in the form } \\
\text { of project bond } \\
\text { credit } \\
\text { enhancement }\end{array}$ & GBP 51 million & GBP 45.8 million & EUR 200 million \\
\hline $\begin{array}{l}\text { EIB approval } \\
\text { date }\end{array}$ & February $2015^{2}$ & December 2013 & July 2013 \\
\hline
\end{tabular}

\footnotetext{
${ }^{1}$ At the moment, it is estimated that institutional investors (e.g.: pension funds, life insurance companies, sovereign wealth funds) have around EUR 14 trillion in assets in Europe, while only a fraction of these (under 3\%) are infrastructure assets [7]. In theory, the long-term liabilities of these investors would be perfectly matched by infrastructure assets, by definition long-term assets.

${ }^{2}$ Although the PBI pilot phase had officially ended, as it usually happens with EU funding, it was probably extended for a couple of more years. However, this might be an indication of the limited pool of eligible/ bankable projects.
} 


\begin{tabular}{|c|c|c|c|}
\hline & $\begin{array}{c}\text { Gwynt y Mor } \\
\text { offshore } \\
\text { transmission link }\end{array}$ & $\begin{array}{c}\text { Greater Gabbard } \\
\text { offshore } \\
\text { transmission link }\end{array}$ & $\begin{array}{c}\text { Castor energy storage } \\
\text { project }\end{array}$ \\
\hline Project aim & $\begin{array}{l}\text { Connect the } 2^{\text {nd }} \\
\text { largest offshore farm } \\
\text { in the world (576 } \\
\text { MW) to the } \\
\text { transmission grid }\end{array}$ & $\begin{array}{l}\text { Connect offshore } \\
\text { wind farm (140 } \\
\text { turbines) to the } \\
\text { transmission grid }\end{array}$ & Gas storage \\
\hline \multirow[t]{2}{*}{ Observations } & & $\begin{array}{l}\text { Mid-range bond } \\
\text { maturities (until } \\
\text { 2023) } \\
\text { Three times } \\
\text { oversubscribed at } \\
\text { very competitive } \\
\text { spreads [7] }\end{array}$ & $\begin{array}{l}\text { The EIB guarantee by far } \\
\text { exceeded the total PBI } \\
\text { budget allocated for } \\
\text { energy, so the added value } \\
\text { of the EU budget becomes } \\
\text { questionable. } \\
\text { The deal was closed in a } \\
\text { matter of weeks, proving } \\
\text { that the EC contribution is } \\
\text { significant in the sense of } \\
\text { increasing the } \\
\text { trustworthiness of the } \\
\text { project. }\end{array}$ \\
\hline & \multicolumn{3}{|c|}{$\begin{array}{l}\text { With the EC - EIB propping, all projects achieved an increase in their } \\
\text { project rating provided by Moody's, thus allowing them to become } \\
\text { bankable for the rest of the senior debt needed to finance the projects. } \\
\text { Mid-term evaluators of the PBI pilot phase consider investors wouldn't } \\
\text { have been attracted to these projects without the EIB - EC intervention. } \\
\text { Furthermore, the same evaluation report estimates, based on stakeholder } \\
\text { interviews, that "the financing would be much more expensive (measured } \\
\text { as a difference of more than 50bps on the all-in interest rate) if the PBCE } \\
\text { would not have been involved." (Ernst \& Young, 2014). }\end{array}$} \\
\hline
\end{tabular}

Based on the case studies above and on general literature review (Vagliasindi, 2013; Kappeler and Nemoz, 2010, etc.), it seems that PPPs employ a bunch of political risks, from the risk that the public may get the impression of "masked privatization", which can lead to ideological clashes, to the fact that lack of transparency in the management setup leads to integrity suspicions and to the fact the public may want to see their money invested elsewhere. Expropriation, war, civil disturbances, regulatory changes and the risk that, in the future, moving PPPs on the balance sheet may lead to significant reputational risks, are other types of political risks. The most important one may be, though, that due to the highly technical nature of projects, political rivals might easily and successfully challenge the value for money proposition of the project. Financial risks are even more consistent: an improper financial risk allocation between the private and the public

${ }^{1}$ Author's own critical observation, not expressed anywhere on the Commission's website. 
partner, may lead to either economic inefficiencies up to outright bankruptcy on behalf of the private service provider. Other financial risks are cost overruns throughout the lifetime of the project and macro risks (e.g.: interest rates, currency rates), but also a miscalculation of the payment formula in case of demographic changes or changes in the consumption patterns. In genral, the more complex the financial arrangement and the higher the value of the project, the greater the financial risks. On the other hand, since the project is non-recourse, usually, in case of financial difficulties of the project company, the government will bail it out. From an implementation perspective the public authority needs to have extremely well trained specialists and very high administrative capacity to be able to perform the deal preparation, structuring, and then continuous monitoring. If procurement arrangements are not clear and stable, there may be a lot of delays in bidding and contract implementation. Low contractual performance of sub-contractors may impact the level of customer service, so a very clear definition of the performance indicators would be needed, which again requires high public administration capacity. Due to more recent fiscal tightening rules, PPPs may not qualify as offthe-balance, so existing PPPs might push the public authority in severe debt and new ones risk not being contracted at all. Furthermore, in the absence of highquality standard documentation, potential efficiencies and savings are not reached. To date, the overwhelming majority of PPPs have been done in the transportation sector, yet project promoters in the energy sectors do not have, for instance, access to the knowledge accumulated in the transportation sector. At the same time, what has worked in one sector may not work in the other, so sector-specific PPP expertise should be developed at the level of contracting authorities and lenders.

\section{Conclusions}

When it comes to private sources of financing, this usually meant large utilities, which continued to play, until recently, a significant role in financing the European energy sector, including when it came to new capacity. However, their credit worthiness has seriously deteriorated and their business model is significantly under threat. CAPEX investments through loans or equity have been slashed, and tighter financial regulations prevent further investments through these classical channels. At the same time, private financing has significant drawback when it comes to filling the investment gap, in particular given the investment drivers analysed above, because of its short-termism and withdrawal from the real economy.

As a result, PPPs, in their various shapes and sizes, remain the best bet for meeting the investment imperative of the EU energy market. The apparent collapse of the European PPP market in the aftermath of the financial crisis seems to have halted, with encouraging figures for 2014 (e.g.: the 15\% y.o.y of EIB-financed PPPs). More definitional clarity (but also flexibility) as to what constitutes a PPP in the energy sector would implicitly lead to a more accurate monitoring of EU-level developments. In my opinion, the current monitoring setup provided by EPEC does 
not adequately cover all energy PPPs that are taking place in Europe. Out of all energy PPPs, those in energy efficiency seem to be most promising, as exemplary case studies (e.g.: the Berlin Energy Saving Programme) indicate. However, the imperative of linking EU energy markets (both gas and electricity) by supplementing cross-border interconnections and by investments in transmission infrastructure on the territories of Member States probably remains the most serious challenge for attracting investments in the European energy sector. These particular projects, because of the basic features of energy transmission companies, should be considered PPPs and supported more intensely by public authorities. However, political, financial and implementation risks of PPPs in the energy sector should not be overlooked, as case studies (e.g. the Seeboard Powerlink) clearly confirm. A transparent and comprehensive value for money assessment in the preparation phase of the PPP remains equally important as a high administrative capacity for implementation and monitoring of the public authority, which can be, in its turn, significantly increased through regulatory and contractual clarity. In my opinion, to avoid blockages, PPPs should continue to be treated as off-balance sheet investments, provided public authorities maintain a very clear record and accounting of these projects, which are still public finance liabilities.

\section{References}

1. Austvik, Ole Gunnar. (2016). The Energy Union and security-of-gas supply. Energy Policy. 96. 372-382. 10.1016/j.enpol.2016.06.013

2. Baker, M, et al, 2018, Financing the Response to Climate Change: The Pricing and Ownership of US Green Bonds, available at https://www.brookings.edu/ wp-content/uploads/2018/07/Wurgler-J.-et-al..pdf, last accessed on 15 June 2019

3. Bloomberg New Energy Finance (BNEF), 2018, Clean Energy Investment Trends, available at https://data.bloomberglp.com/professional/sites/24/BNEFClean-Energy-Investment-Trends-2018.pdf, last accessed on 24 June 2019

4. Birdlife, 2013, "Projects of common interest? Case studies of environmentally damaging and controversial EU energy infrastructure 'projects of common interest' (PCIs) “, Internet Source:http://www.birdlife.org/sites/default/files/ attachments/PCI_case_studies.pdf (accessed on September 2015)

5. Blyth et al, 2015, "Financing the UK power sector: Is the money available?", in Energy Policy, Volume 87, December 2015, pp 607 - 622

6. CALDECOTT, B. 2010. Green Infrastructure Bonds: Accessing the scale of low cost capital required to tackle climate change. Climate Change Capitalișp:

7. Carlini, E.; Birkebaek, J.; Schroeder, R. (2018). A Power Sector in Transition Understanding Transition Towards a Cleaner Grid and how Distributed Energy Resources Affect the Design and Operation of Electric Power Systems 
8. Clark, Andrew, 2003, "Black-out blamed on tube sell-out", Internet Source $\mathrm{http} / / / \mathrm{www}$. theguardian.com/uk/2003/aug/29/transport.publicservices (accessed on September 2015)

9. Correlje, A., van der Linde, C., 2006. Energy supply and geopolitics: a European perspective. Energy Policy 34 (5), 532-543

10. Cuttaree, Vickram; Mandri-Perrott, Cledan, 2011, "Public-Private Partnerships in Europe and Central Asia: Designing Crisis-Resilient Strategies and Bankable Projects", World Bank, Internet Source: http://openknowledge. worldbank.org/handle/10986/2774 (accessed on September 2015)

11. Dore, R., 2008, "Financialization of the Global Economy", in Industrial and Corporate Change 17, 1097-1112

12. Dreger, Christian and Reimers, Hans-Eggert, (2016), Does public investment stimulate private investment? Evidence for the euro area, Economic Modelling, 58, issue C, p. 154-158

13. Ernst \& Young, 2014, "Ad-hoc audit of the pilot phase of the Europe 2020 Project Bond Initiative", Internet Source: http://ec.europa.eu/dgs/economy_ finance/evaluation/pdf/mid_term_eval_pbi_pilot_phase_en.pdf (last accessed on September 2015)

14. European Investment Bank, 2016, Restoring EU competitiveness. 2016 updated version, available at https://www.eib.org/attachments/efs/restoring eu_competitiveness_en.pdf, last accessed on 24 June 2019

15. Fight, Andrew, 2008, "Introduction to Project Finance", Butterworth Heinemann

16. Gaventa, Jonathan, 2014, "Energy Security and the Connecting Europe Facility. Maximizing Public Value for Public Money", Internet Source: http://www.e3g.org/docs/E3G_Energy_Security_and_the_Connecting_Europe _Facility_110914.pdf (accessed on September 2015)

17. Graeme A. Hodge; Greve, Carsten (2007), "Public-Private Partnerships: An International Performance Review", in: Public Administration Review, Vol. 67, No. 3 (May - Jun., 2007), pp. 545-558

18. Haldane, A.G., 2011, "The Short Long", in 29th Société Universitaire Européene de Recherches Financières Colloquium: New Paradigms in Money and Finance?, Brussels

19. Hallikeri, Varun 2012, "How Not to Bungle a Public - Private Partnership. Lessons from the London Underground PPPs", The Institute for Business in a Global Context, Internet Source: http://fletcher.tufts.edu/ /media/Fletcher/ Microsites/IBGC/pdf/Student\%20Research/Final\%20Halikeri.pdf (accessed on September 2015)

20. Inderst, Georg, 2013. "Private infrastructure finance and investment in Europe," EIB Working Papers 2013/02, European Investment Bank (EIB) 
21. Ingram, G.K., and Y.-H. Hong, Value capture and land policies, The Lincoln Institute of Land Policy, Bolton (2012)

22. JACOBSSON, R., JACOBSSON, S. (2012), The Emerging Funding Gap for the European Energy Sector: Will The Financial Sector Deliver?, Environmental Innovation and Societal Transitions, 5, 49-59

23. Kappeler, Andreas and Nemoz, Mathieu, 2010, "Public-Private Partnerships in Europe: Before and During the Recent Financial Crisis", European Investment Bank, Economic and Financial Report 2010

24. Kay, J., 2012, "The Kay review of UK equity markets and long-term decision making" Available at: https://www.gov.uk/government/publications/the-kayreview-of-uk- equity-markets-and-long-term-decision-making-final-report, last accessed on 23 February 2014

25. Kayser, Dirk. (2013). Recent Research in Project Finance - A Commented Bibliography. Procedia Computer Science. 17. 729-736. 10.1016/ j.procs.2013.05.094

26. Lam, Patrick T.I. \& Law, Angel O.K., 2018. "Financing for renewable energy projects: A decision guide by developmental stages with case studies," Renewable and Sustainable Energy Reviews, Elsevier, vol. 90(C), pages $937-944$

27. Lindquist, H, (2017), "The Journey of Reinventing the European Electricity Landscape", in Lawrence, J, Renewable Energy Integration: Practical Management of Variability, Academic Press, 2017

28. Lu, Zheng \& Peña-Mora, Feniosky \& Robert Wang, Xiaodong \& Shen, Charles \& Riaz, Zainab. (2015). Social Impact Project Finance: An Innovative and Sustainable Infrastructure Financing Framework. Procedia Engineering. 123. 300-307. 10.1016/j.proeng.2015.10.094

29. Mathews, J., et al, 2010, Mobilizing private finance to drive an energy industrial revolution, in Energy Policy, 2010, vol. 38, Issue 7, 3263-3265

30. MAZARS 2012. UK ONSHORE WIND INVESTMENT How long can the sector continue to buck the trend?

31. Mazzucato, M. and Penna, C., 2015, "The Rise of Mission-Oriented State Investment Banks: The Cases of Germany's KfW and Brazil's BNDES", Working Paper Series SWPS 2015-26, Science Policy Research Unit, available at http://sro.sussex.ac.uk/id/eprint/61972/1/2015_26_SWPS_Mazzucato_Penna.pdf, last accessed on 15 June 2019

32. Mitchell, J. Accountability and the management of public authorities in the United States

33. vol. 59, International Review of Administrative Sciences, SAGE (1993), pp. $477-492$

$376 \quad$ Volume 20, Issue 3, July $2019 \quad$ Review of International Comparative Management 
34. Moody's, Green Bonds: Key Numbers and Trends, 2017, available at https://www.moodys.com/sites/products/ProductAttachments/MIS_Green_Bon ds_2018_key_trends.pdf, last accessed 15 June 2019

35. Pagano, M. and D. Perry, Financing infrastructure in the 21st century city,

36. Public Works Management \& Policy, 12 (1) (2008), pp. 22-23 July

37. Polzin, F., 2017, "Mobilizing private finance for low-carbon innovation - A systematic review of barriers and solutions", in Renewable and Sustainable Energy Reviews, Volume 77, September 2017, pages 525 - 535

38. Puka, Lidia and Szulecki, Kacper, Beyond the 'Grid-Lock' in German-Polish Electricity Interconnectors (January 12, 2014). Available

39. Renneboog, Luc \& Horst, Jenke \& Zhang, Chendi. (2008). Socially Responsible Investments: Institutional Aspects, Performance, and Investor Behavior. Journal of Banking \& Finance. 32. 1723-1742. 10.1016/j.jbankfin.2007.12.039.

40. Scope Ratings, April 2016, “Application Study: European Utilities”, available online at https://www.google.com/url?sa=t\&rct=j\&q=\&esrc=s\&source= web\&cd=2\&ved=2ahUKEwjU27Hb9friAhVBIYsKHSkjBQAQFjABegQIBB

AC\&url=https\%3A\%2F\%2Fwww.scoperatings.com\%2Fstudy $\% 2$ Fdownload $\%$ 3Fid\%3D75efd8dc-3376-467e-b7fa-7644a00d013a\%26q\%3D1\&usg= AOvVaw3hrRNAN4XCL0Bj642RaEUL, last accessed 15 June 2019

41. STANDARD \& POOR'S 2013. Industry Report Card: New Finance Structures Set To Spur A Revival Of Debt Issuance In The Project Finance Industry

42. Steffen, Bjarne, 2018. "The importance of project finance for renewable energy projects," Energy Economics, Elsevier, vol. 69(C), pages 280-294

43. Steuerle, C.E. , Dead men ruling: How to restore fiscal freedom and rescue our future, The Century Foundation (2014)

44. Thomson Reuters, 2016. Global Project Finance Review - Full Year 2015

45. Vagliasindi, Maria, 2013, "Revisiting Public-Private Partnerships in the Power Sector", World Bank, Internet Source: https://openknowledge.worldbank.org/ bitstream/handle/10986/13118/761830PUB0EPI00LIC00pubdate03014013.pdf ?sequence $=1$ (accessed on September 2015) 